\title{
Sistem Pengenalan Penutur dengan Metode Mel-frequency Wrapping
}

\author{
Ali Mustofa \\ Jurusan Teknik Elektro, Universitas Brawijaya \\ Jl. MT. Haryono 167 Malang 65145 \\ Phone/Fax: 0341554166 \\ Email: a tofa@yahoo.com
}

\begin{abstract}
ABSTRAK
Pengenalan penutur adalah proses identifikasi suara seseorang.. Pengenalan penutur berguna untuk otentikasi biometrik dan komunikasi antara komputer dengan manusia. Teknik Mel Frequency Cepstral Coefficients (MFCC) digunakan untuk ekstraksi ciri dari sinyal wicara dan membandingkan dengan penutur tak dikenal dengan penutur yang ada dalam database. Filter bank digunakan sebagai pembungkus (wrapping) mel frekuensi. Vector Quantization (VQ) adalah proses meletakkan vektor-vektor ciri yang besar dan menghasilkan ukuran vektor-vektor yang kecil yang berhubungan dengan distribusi centroid. Algoritma K-mean digunakan untuk kluster. Dalam tahap pengenalan, ukuran distorsi berdasarkan minimisasi jarak Euclidean digunakan untuk mencocokkan penutur tak dikenal dengan penutur dalam database. Database wicara menggunakan 10 penutur berbeda dengan MFCC 12, 20 codebook, dan 16 centroid.
\end{abstract}

Kata kunci: penutur, mel-frequency cepstral coefficients, vector quantization, K-mean

\section{ABSTRACT}

Speaker recognition is the process of identifying a person based on his voice. Speaker recognition has several useful applications including biometric authentication and intuitive human computer interaction. the Mel Frequency Cepstral Coefficients (MFCC) technique is used to extract features from the speech signal and compare the unknown speaker with the exist speaker in the database. the filter bank is used to wrap the Mel frequency. VQ (vector Quantization) is a process of taking a large set of feature vectors and producing a smaller set of measure vectors that represents the centroids of the distribution. In this method, the K means algorithm is used to do the clustering. In the recognition stage, a distortion measure which based on the minimizing the Euclidean distance was used when matching an unknown speaker with the speaker database. Speech database used 10 different speakers with MFCC 12, 20 codebooks, and 16 centroids.

Keywords: speaker, mel-frequency cepstral coefficients, vector quantization, K-mean

\section{PENDAHULUAN}

Suara digunakan oleh manusia untuk berkomunikasi. Suara manusia berguna untuk menyampaikan ide, keinginan, informasi kepada manusia lainnya. Lintasan vokal manusia dan artikulasi adalah organ biologi dengan sifat tak linier dan ini beroperasi tidak hanya dibawah kontrol kesadaran tetapi juga dipengaruhi oleh sifat gender dan keadaan emosional [1]. Oleh sebab itu ucapan manusia bervariasi membentuk pengenalan wicara dan ini mempunyai masalah yang sangat kompleks [2].

Secara garis besar sistem pengenalan wicara merupakan suatu usaha untuk dapat menghasilkan suatu mesin cerdas yang mampu mengenali ucapan manusia. Kesulitan yang paling mendasar adalah bagaimana melakukan ekstraksi terhadap sinyal ucapan menjadi beberapa parameter yang dapat digunakan untuk klasifikasi ucapan secara efisien.

Catatan: Diskusi untuk makalah ini diterima sebelum tanggal 1 Desember 2007. Diskusi yang layak muat akan diterbitkan pada Jurnal Teknik Elektro volume 8, nomor 1, Maret 2008.
Pengenalan penutur adalah proses secara otomatis mengenali siapa yang bicara dengan dasar informasi individu yang mengandung gelombang wicara [3] . Teknik ini memungkinkan menggunakan suara penutur untuk memverifikasi identitas wicara dan mengontrol layanan seperti menekan nomor telepon dengan suara (voice dialing), perbankan dengan telepon, belanja melalui telepon, layanan akses melalui basis data (database), layanan informasi, surat dengan suara (voice mail), kontrol keamanan area rahasia, dan akses jarak jauh dengan komputer.

Penelitian ini membangun sistem pengenalan penutur secara otomatis. Semua penutur mengucapkan satu kata tunggal yang sama dalam pelatihan dan akan diuji (testing) kemudian. Daftar bahasa yang digunakan adalah kata sering digunakan dalam pengetesan pengenalan penutur karena sering digunakan untuk berbagai aplikasi. Sebagai contoh, pengguna harus mengucapkan PIN (Personal Identification Number) untuk membuka pintu laboratorium, atau pengguna harus mengucapkan nomer kartu kredit melalui saluran telepon. Dengan memeriksa karakteristik 
suara dari input ucapan dengan menggunakan sistem pengenalan penutur otomatis, sistem ini dapat ditambahkan tingkat keamanan.

Dalam penelitian ini dilakukan proses pengenalan penutur dengan menggunakan metode Mel-frequency Wrapping. Dengan pemrosesan Mel-frequency Wrapping ini adalah menirukan perilaku dari pendengaran manusia sehingga dapat mengenali ucapan dari penutur.

\section{PENGENALAN PENUTUR}

Pengenalan penutur dapat diklasifikasikan menjadi identifikasi dan verifikasi. Identifikasi penutur adalah proses penentuan penutur yang terdaftar sesuai dengan ucapannya. Verifikasi penutur adalah proses diterima atau ditolaknya klaim identitas penutur [4].

Metode pengenalan penutur dibagi menjadi metode text-independent dan text-dependent. Dalam sistem dengan ucapan bebas (text-independent), model penutur menangkap karakteristik wicara seseorang dengan kata yang bebas. Dalam sistem ucapan tertentu (text-dependent), pengenalan identitas penutur berdasarkan frasa yang spesifik, seperti kata sandi (password), nomer kartu kredit, kode PIN, dan sebagainya [5].

Semua teknologi pengenalan penutur, identifikasi dan verifikasi, text-independent dan text-dependent, masing-masing mempunyai keuntungan dan kelemahan dan mungkin memerlukan perlakuan dan teknik yang berbeda. Pemilihan teknologi yang digunakan tersebut harusnya disesuaikan dengan aplikasi tertentu

Pada tingkat tertinggi, semua sistem pengenalan penutur berisi dua modul utama seperti dalam Gambar 1 yaitu ekstraksi ciri dan penyesuaian ciri. Ekstraksi ciri adalah proses yang mengekstrak sejumlah kecil data dari sinyal suara kemudian digunakan untuk merepresentasikan masing-masing penutur. Penyepadanan ciri melibatkan prosedur untuk mengidentifikasi penutur tak dikenal dengan membandingkan ciri-ciri terekstraksi dari input suara pria atau wanita dengan kumpulan (set) penutur yang dikenal.

Semua sistem pengenalan penutur harus melayani dua fasa yang berbeda. Pertama mengacu pada bagian yang terdaftar atau fasa pelatihan kemudian yang kedua mengacu pada bagian operasi atau fasa pengetesan. Dalam fasa pelatihan, masing-masing penutur yang terdaftar mempunyai sampel wicaranya sehingga sistem dapat melatih model referensi wicaranya tersebut. Dalam sistem verifikasi ambang spesifik penutur dikomputasi dari sampel-sampel pelatihan. Selama fasa pengetesan (operasional), input wicara disepadankan dengan model-model referensi yang disimpan dan keputusan pengenalan dibuat [5].

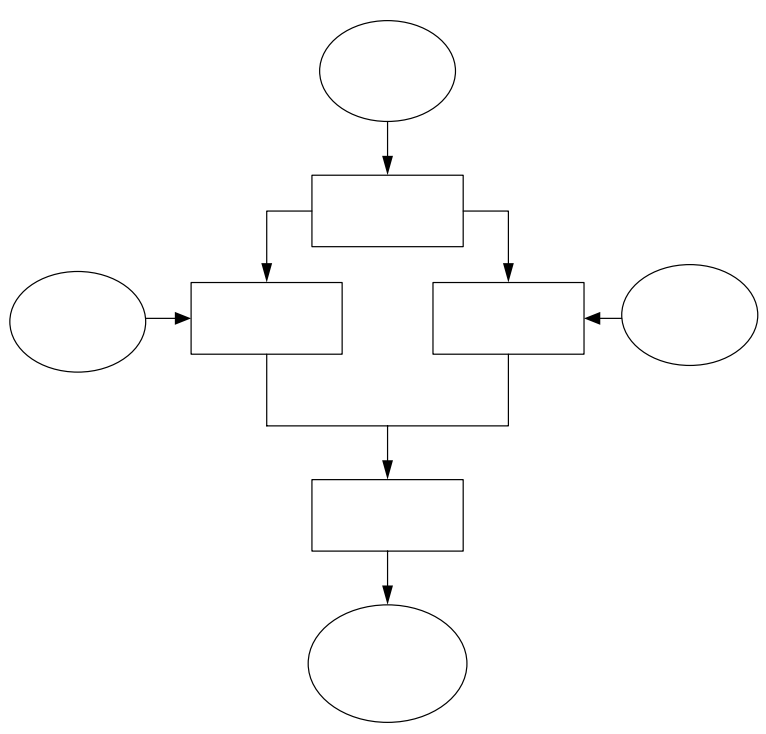

Gambar 1. Struktur dasar sistem pengenalan penutur.

Pengenalan penutur adalah tugas yang sulit dan ini masih diteliti lebih lanjut. Pengenalan penutur otomatis bekerja berdasarkan karakteristik wicara seseorang/person yang unik dalam wicaranya. Akan tetapi tugas ini tertantang oleh varians input sinyal wicara. Prinsip sumber varians berasal dari penuturpenutur itu sendiri. Sinyal wicara dalam bagian pelatihan dan pengetesan dapat berbeda karena banyak fakta seperti perubahan suara karena waktu, kondisi kesehatan (karena sakit flu), tingkat bicara, dan sebagainya [5]. Ada juga karena faktor lain, kemajemukan penutur, sehingga menantang teknologi pengenalan penutur. Contoh ini adalah noise akustik dan variasi dalam lingkungan perekaman data (seperti penutur menggunakan perangkat rekaman) yang berbeda.

\section{EKSTRAKSI CIRI WICARA}

Dalam penelitian ini mengubah bentuk gelombang wicara dengan beberapa jenis representasi parametrik (pada laju informasi rendah).

Sinyal wicara mempunyai waktu lambat terhadap perubahan sinyal (atau disebut quasi-stationary). Jika ini diujikan dengan periode waktu yang cukup singkat (antara 5 dan $100 \mathrm{msec}$ ), karakteristiknya cukup stasioner. Akan tetapi, dengan periode waktu yang panjang (pada 1/5 sec atau lebih) karakteristik sinyal 
berubah terhadap reflek suara wicara yang dihasilkan. Analisis spektral waktu singkat adalah cara paling umum digunakan untuk mengkarakterisasi sinyal wicara.

\section{PEMROSESAN KOEFISIEN $M E L$ - FREQUENSCY CEPSTRUM}

Tujuan utama dari pemroses MFCC adalah menirukan perilaku dari pendengaran manusia. Adapun prosesnya sebagai berikut.

\section{Frame Blocking}

Dalam langkah ini sinyal wicara kontinyu diblok menjadi frame-frame $N$ sampel, dengan frame-frame berdekatan dengan spasi $M(M<N)$. Frame pertama terdiri dari $N$ sampel pertama. Frame kedua dengan $M$ sampel setelah frame pertama, dan overlap dengan $N-M$ sampel. Dengan cara yang sama, frame ketiga dimulai $2 M$ sampel setelah frame pertama (atau $M$ sampel setelah frame kedua) dan overlap dengan $N$ $2 M$ sampel. Proses ini berlanjut hingga semua wicara dihitung dalam satu atau banyak frame. Nilai tipikal untuk $N$ dan $M$ adalah $N=256$ dan $M=100$.

\section{Windowing}

Langkah berikutnya adalah pemrosesan dengan window pada masing-masing frame individual untuk meminimalisasi sinyal tak kontinyu pada awal dan akhir masing-masing frame. Window dinyatakan sebagai $w(n), \quad 0 \leq n \leq N-1$, dengan $N$ adalah jumlah sampel dalam masing-masing frame, $x_{1}(n)$ adalah sinyal input dan hasil windowing adalah $y_{1}(n)$.

$$
y_{1}(n)=x_{1}(n) w(n), \quad 0 \leq n \leq N-1
$$

Jenis window yang digunakan adalah window Hamming [4].

$$
w(n)=0.54-0.46 \cos \left[\frac{2 \pi n}{N-1}\right], \quad 0 \leq n \leq N-1
$$

dengan $N$ adalah jumlah sampel.

\section{Transformasi Fourier Cepat}

Langkah pemrosesan berikutnya adalah transformasi fourier cepat/ fast fourier transform (FFT), FFT ini mengubah masing-masing frame $N$ sampel dari domain waktu menjadi domain frekuensi. FFT adalah algoritma cepat untuk mengimplementasikan discrete fourier transform (DFT) dengan didefinisikan pada kumpulan (set) $N$ sampel, $\left\{X_{n}\right\}$, seperti berikut ini [7].

$$
X_{n}=\sum_{k=0}^{N-1} x_{k} e^{-2 \pi j k n / N}, \quad n=0,1,2, \ldots, N-1
$$

dengan, $x_{k}=$ deretan aperiodik dengan nilai $N$

$N=$ jumlah sampel

\section{Mel-Frequency Wrapping}

Studi psikofisikal menunjukkan bahwa persepsi manusia dari kandungan frekuensi suara pada sinyal wicara tidak mengikuti skala linier. Untuk masingmasing nada dengan frekuensi aktual, $f$ dalam $\mathrm{Hz}$, pitch diukur dengan skala ' $m e l$ '. Skala mel-frequency adalah frekuensi linier berada dibawah $1000 \mathrm{~Hz}$ dan bentuk logaritmik berada diatas $1000 \mathrm{~Hz}$. Sebagai titik referensi adalah pitch dengan tone $1 \mathrm{kHz}, 40 \mathrm{~dB}$ diatas nilai batas ambang pendengaran, ini dinyatakan $1000 \mathrm{mel}$. Pendekatan persamaan untuk menghitung mel dalam frekuensi $f(\mathrm{~Hz})$ adalah [1][6].

$$
\operatorname{mel}(f)=2595 \times \log _{10}(1+f / 700)
$$

Salah satu pendekatan simulasi spektrum yaitu menggunakan filter bank, satu filter untuk masingmasing komponen mel-frequency yang diinginkan. Filter bank mempunyai respon frekuensi bandpass segitiga dan jarak bandwidth ditentukan oleh konstanta interval mel-frequency.

\section{Cepstrum}

Langkah selanjutnya yaitu mengubah spektrum $\log$ mel menjadi domain waktu. Hasil ini disebut mel frequency cepstrum coefficient (MFCC). Reprentasi cepstral dari spectrum wicara memberikan reprentasi baik dari sifat-sifat spektral lokal sinyal untuk analisis frame yang diketahui. Karena koefisien mel spektrum adalah bilangan nyata. Dengan mengubahnya menjadi domain waktu menggunakan discrete cosine transform (DCT). Jika koefisien spektrum daya mel hasilnya adalah $\widetilde{S}_{k}, k=1,2, \ldots, K$, sehingga MFCC dapat dihitung, $\widetilde{c}_{n}$ adalah [8]

$$
\widetilde{c}_{n}=\sum_{k=1}^{K}\left(\log \widetilde{S}_{k}\right) \cos \left[n\left(k-\frac{1}{2}\right) \frac{\pi}{K}\right], \quad n=1,2, \ldots, K
$$

Dimana $\widetilde{c}_{n}$ adalah koefisien cepstrum mel-frequency dan $\widetilde{S}_{k}$ adalah koefisien daya mel.

\section{Vektor Kuantisasi}

VQ atau vektor kuantisasi adalah proses memetakan vektor-vektor dari ruang vektor besar menjadi jumlah terbatas daerah ruang vektor. Masing-masing daerah disebut kluster dan dapat direpresentasikan oleh pusatnya yang disebut codeword. Kumpulan dari semua codeword-codeword disebut codebook. 
Dalam Gambar 5 menunjukkan konsep diagram untuk ilustrasi proses pengenalan. Hanya dua penutur dan dua dimensi dari ruang akustik ditunjukkan. Putaran-putaran mengacu pada vektor-vektor akustik dari penutur 1 dengan tanda lingkaran dan penutur 2 dengan tanda kotak. Dalam fasa pelatihan, VQ codebook penutur-spesifik dibangkitkan untuk masingmasing penutur yang dikenali oleh pengklusteran vektor-vektor akustik pelatihan dari laki-laki atau wanita.

Hasil codeword-codeword (centroid) ditunjukkan dalam Gambar 5 dengan tanda lingkaran hitam dan tanda kotak hitam untuk penutur 1 dan 2. Jarak terdekat antara vektor codeword dari codebook disebut distorsi VQ. Dalam fasa pengenalan ini, input wicara dari suara tak dikenal adalah "vektor terkuantisasi" dengan menggunakan masing-masing codebook yang dilatih dan jarak total distorsi VQ. Penutur dengan VQ codebook dan total distorsinya terkecil akan diidentifikasi.

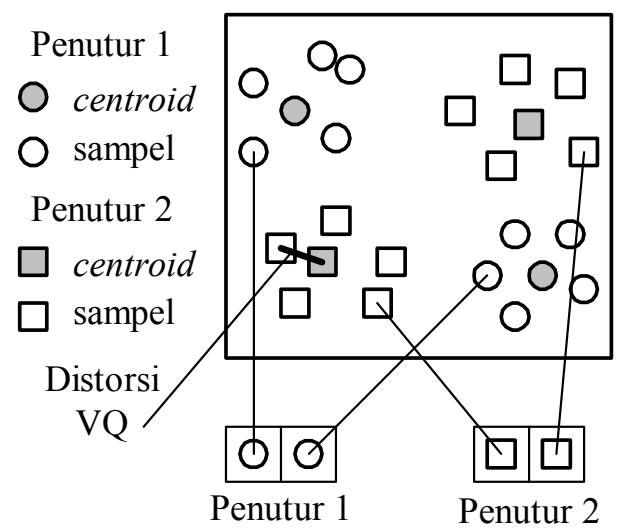

Gambar 5. Formasi VQ codebook antara penutur 1 dan penutur 2 .

\section{Pelatihan Vektor-Vektor}

Selajutnya vektor-vektor akustik diekstraksi dari input wicara dari seorang penutur sebagai set pelatihan vektor-vektor. Sebagaimana penjelasan diatas, langkah penting berikutnya adalah membangun VQ codebook dari penutur yang spesifik dengan menggunakan pelatihan vektor-vektor ini. Algoritma ini dikenal sebagai algoritma LBG (Linde, Buzo, dan Gray) [9], untuk kluster set $L$ pelatihan vektor-vektor menjadi set $M$ codebook vektor-vektor. Algoritma ini secara formal diimplementasikan dengan prosedur rekursif berikut ini:

1. Desain satu vektor codebook, ini adalah centroid dari masukan set pelatihan vektor-vektor (karenanya tak diperlukan iterasi disini).

2. Gandakan ukuran codebook dengan membagi masing-masing codebook sekarang $y_{n}$ sesuai dengan aturan

$$
\begin{aligned}
& y_{n}^{+}=y_{n}(1+\varepsilon) \\
& y_{n}^{-}=y_{n}(1-\varepsilon)
\end{aligned}
$$

dimana $n$ berubah dari 1 ke ukuran codebook sekarang dan $\varepsilon$ adalah parameter pembagi (splitting) (misalnya $\varepsilon=0.01$ )

3. Pencarian neighbor(tetangga) terdekat: untuk masing-masing pelatihan vektor, tentukan codebook dalam codebook yang terdekat dan menetapkan vektor-vektor tersebut yang berhubungan dengan sel (berhubungan dengan codebook terdekat).

4. Centroid terbarukan (update): mem-perbarui codebook dalam masing-masing sel dengan menggunakan centroid dari pelatihan vektor-vektor ini yang ditentukan untuk sel tersebut.

5. Iterasi 1: mengulangi langkah 3 dan 4 sampai jarak rata-rata jatuh dibawah nilai ambang.

6. Iterasi 2: mengulangi langkah 2, 3, dan 4 sampai codebook dengan ukuran $M$ didesain. Algoritma LBG mendesain $M$ vektor codebook dalam langkah ini. Langkah pertama dengan mendesain satu vektor codebook, kemudian menggunakan teknik pemecahan (splitting) pada codebookcodebook untuk menginialisasi pencarian untuk 2 vektor codebook dan melanjutkan proses pemecahan sampai $M$ vektor codebook yang diinginkan akan dapat ditentukan.

Dalam Gambar 6 menunjukkan langkah detil algoritma LBG. Kluster vektor-vektor adalah neighbor terdekat yang menentukan masing-masing pelatihan vektor pada kluster yang berhubungan dengan codebook terdekat. "Penentuan centroid" adalah prosedur centroid terkini. "Mengkomputasi $D$ (distorsi)" yaitu menjumlahkan jarak semua pelatihan vektor-vektor pada neighbor terdekat dan menentukan apakah prosedurnya telah konvergen.

\section{Algoritma K-Means}

Algoritma $K$-mean adalah cara untuk mengkluster vektor-vektor pelatihan untuk mendapatkan vektorvektor ciri. Dalam algoritma ini vektor-vektor dikluster berdasarkan atribut menjadi $K$ partisi. Ini menggunakan $K$-mean data dengan distribusi gaussian untuk mengkluster vektor-vektor tersebut. Tujuan K-mean adalah untuk meminimkan total varians intra-kluster, $V$.

$$
V=\sum_{i=1}^{k} \sum_{j \in s_{i}}\left|x_{j}-\mu_{i}\right|^{2}
$$

dimana ada $K$ kluster $S_{i}, i=1,2,3, \ldots, k$ dan $\mu_{i}$ adalah centroid atau titik mean dari semua titik $x_{j} \in S_{i}$ 


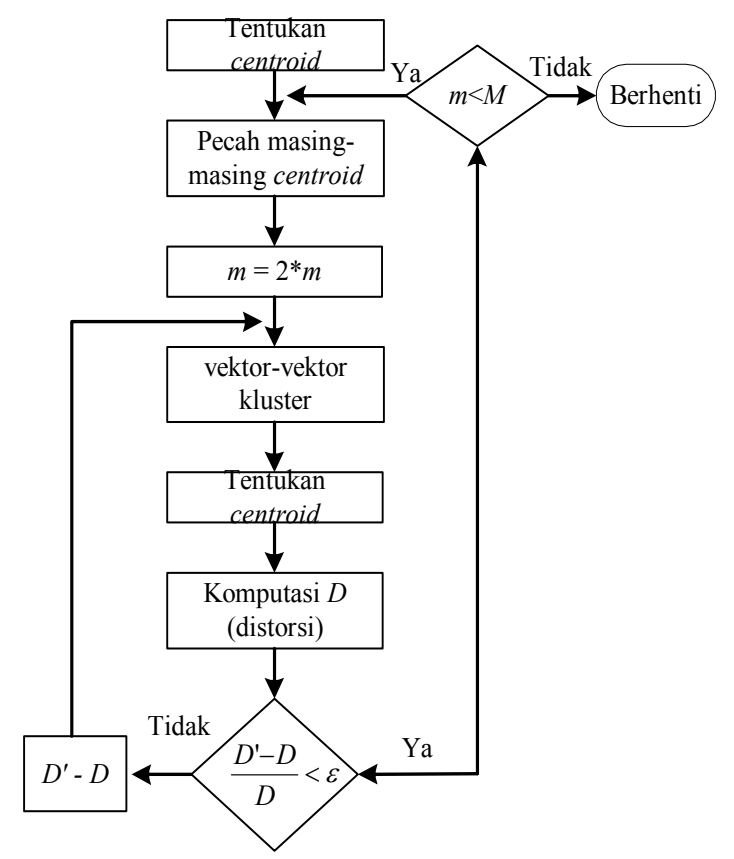

Gambar 6. Diagram alir algoritma LBG.

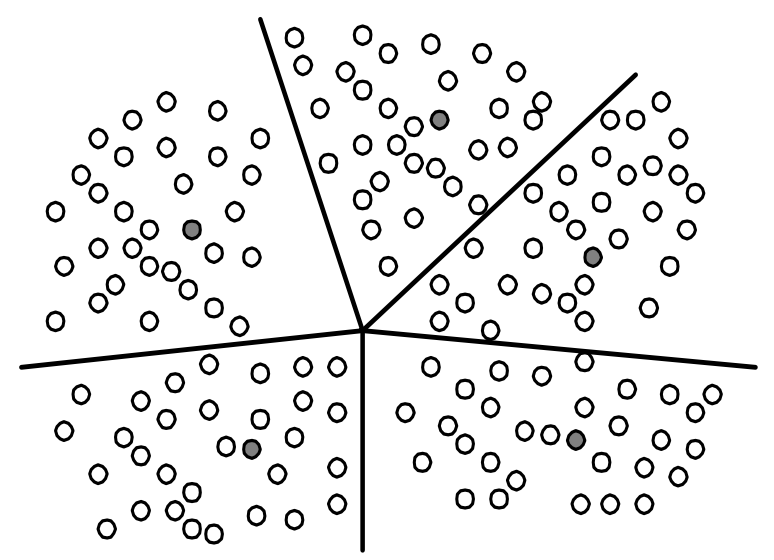

Gambar 7. Ilustrasi K-mean membentuk lima kluster.

\section{Pengukuran Jarak}

Dalam tahap pengenalan penutur, suara penutur yang tak dikenal direperentasikan oleh deretan vektorvektor ciri $\left\{x_{1}, x_{2} \ldots x_{\mathrm{i}}\right)$,dan kemudian ini dibandingkan dengan codebook dari database. Untuk mengidentifikasi pembicara yang tak dikenali, ini dapat dilakukan dengan pengukuran jarak distorsi dari dua kumpulan vektor yang berdasarkan peminiman jarak Euclidean. Jarak Euclidean adalah jarak antar dua titik yang akan diukur dengan suatu aturan, yang dapat dibuktikan oleh aplikasi teorema Pythagorean. Persamaan yang digunakan untuk menghitung jarak Euclidean dapat didefisikan dengan jarak Euclidean antara dua titik $P=\left(p_{1}, p_{2} \ldots p_{\mathrm{n}}\right)$ dan $\mathrm{Q}=\left(q_{1}, q_{2} \ldots q_{\mathrm{n}}\right)$.

$$
\begin{aligned}
& \sqrt{\left(p_{1}-q_{1}\right)^{2}+\left(p_{2}-q_{2}\right)^{2}+\cdots+\left(p_{n}-q_{n}\right)^{2}} \\
& =\sqrt{\sum_{i=1}^{n}\left(p_{i}-q_{i}\right)^{2}}
\end{aligned}
$$

Penutur dengan jarak distorsi terkecil dipilih untuk diidentifikasi seperti orang yang tak dikenal.

\section{METODE PENELITIAN}

Metode yang digunakan dalam penelitian ini adalah pertama pengambilan sampel dilakukan sebanyak 10 orang penutur dengan masing-masing penutur mengucapkan satu pola kata yang telah ditentukan. Kata-kata tersebut adalah kata /kampus/. Pola kata dari masing-masing penutur tersebut disimpan dan kemudian dilatihkan secara bersamaan ke dalam sistem pengenalan penutur. Yang kedua adalah memroses koefisien mel-frequency cepstrum tujuannya adalah menirukan perilaku dari pendengaran manusia. Yang ketiga adalah proses pelatihan. Dalam proses pelatihan pola kata dimasukkan secara urut mulai penutur 1 dengan pola kata/kampus/. Kemudian penutur 2 dengan pola kata yang sama, demikian seterusnya sampai pembicara ke-10 (pelatihan data set). Dalam proses pelatihan ini untuk mengenali pola kata yang dilatihkan sesuai target yang ditentukan pula. Yang keempat adalah menguji penutur dengan MFCC dan VQ untuk mengenali penutur. Yang kelima yaitu menganalisa dan pengambilan kesimpulan.

Lebih jelasnya tahapan penelitian ini dapat dilihat dalam Gambar 8.

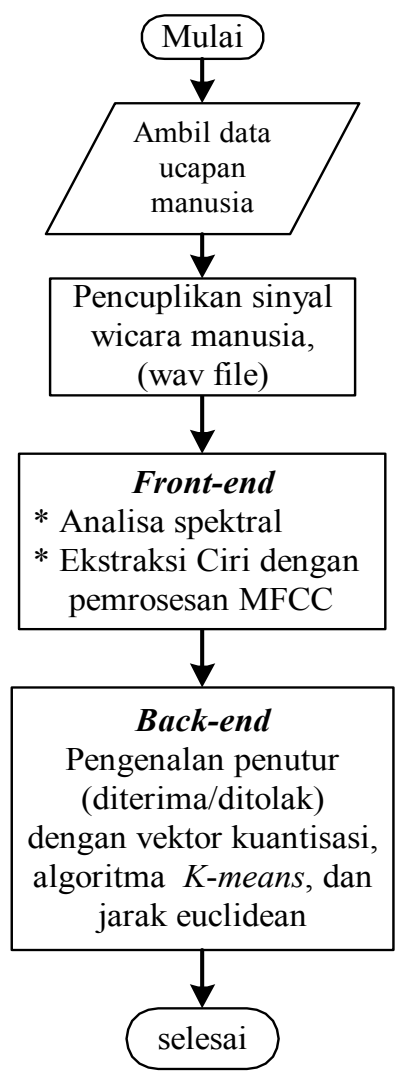

Gambar 8. Diagram alir sistem pengenalan penutur dengan metode mel-frequency. 


\section{HASIL DAN PEMBAHASAN}

Berdasarkan hasil pengujian yang dilakukan berulang-ulang dengan frekuensi sampling $12 \mathrm{kHz}$, ternyata suatu sinyal wicara memiliki suatu ciri yang istimewa. Suatu sinyal wicara merupakan suatu fungsi yang bergantung waktu. Walaupun demikian pada suatu selang waktu tertentu yaitu kira-kira sepanjang $20 \mathrm{~ms}$, sinyal tersebut merupakan fungsi yang tidak bergantung waktu. Pada analisa ini akan diberikan sebuah contoh suatu bentuk sinyal wicara dari suatu penutur. yang mengucapkan kata /kampus/ selama 2.1535 second.

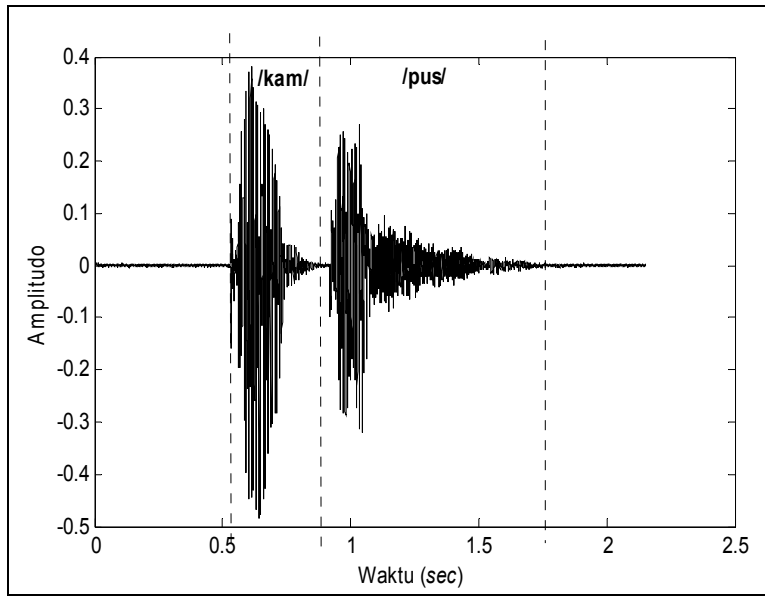

Gambar 9. Bentuk sinyal wicara/kampus/ sepanjang 2.1535 second.

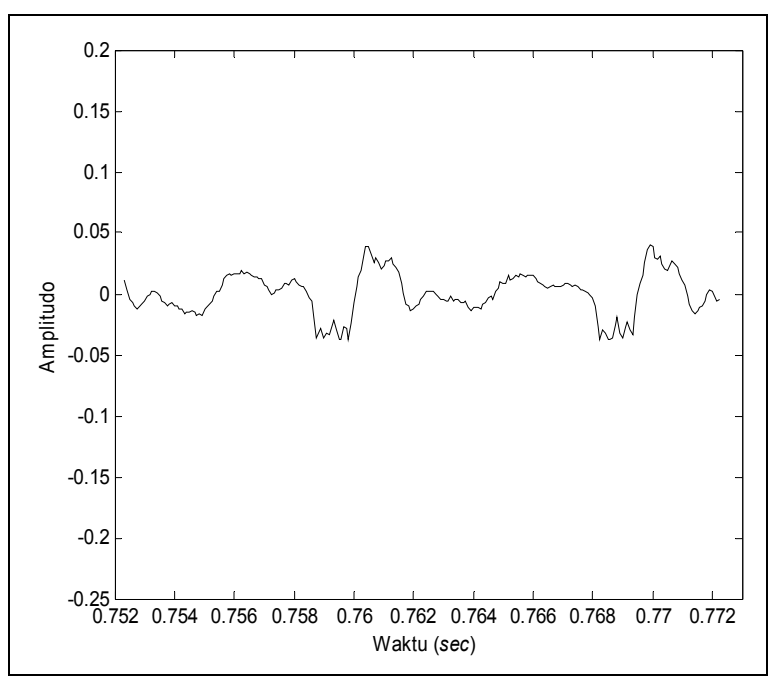

Gambar 10. Bentuk sinyal sepanjang $20 \mathrm{~ms}$.

\section{ANALISA DOMAIN FREKUENSI}

Setelah pemrosesan dengan window, maka akan dianalisa sinyal dalam domain frekuensi yaitu mengubah domain waktu ke domain frekuensi dengan menggunakan transformasi Fourier. Dan hasilnya sinyal tersebut akan dinyatakan dalam bentuk decibel $(\mathrm{dB})$. Setelah proses pe-window-an dan transformasi fourier maka dapat digambarkan spektrumnya dengan panjang window atau jumlah sampel per frame $(N)$ adalah 256 dan pergeseran ke frame berikutnya $(M)$ adalah 100.

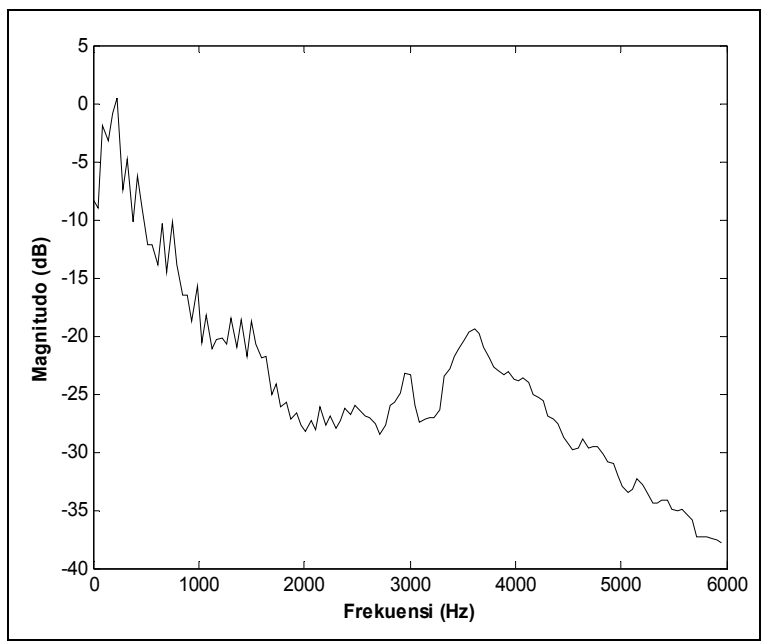

Gambar 11. Spektum sinyal dengan panjang window, $N=256$ dan $M=100$ pada kata /kampus/.

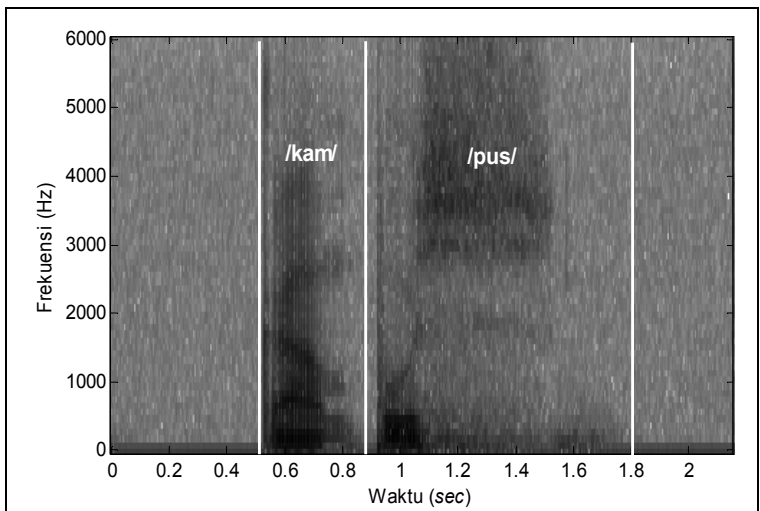

Gambar 12. Spektogram sinyal wicara /kampus/, $M$ $=50$ dan $N=128$.

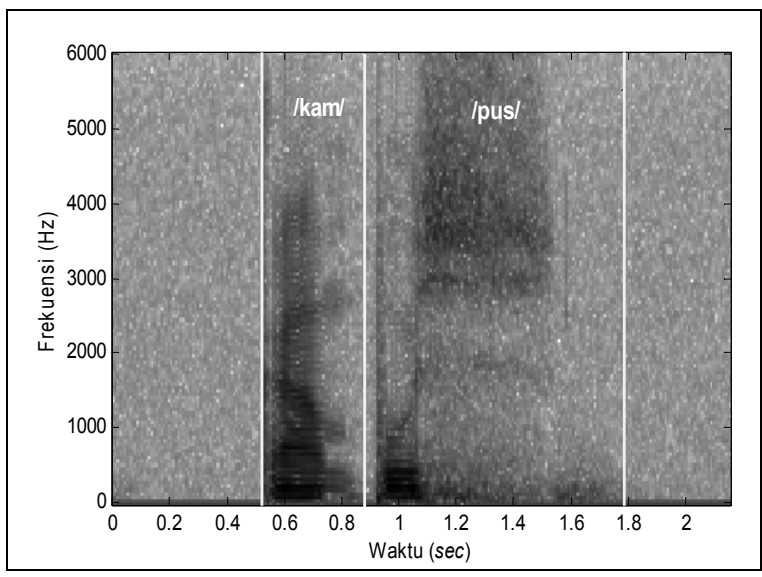

Gambar 13. Spektogram sinyal wicara /kampus/, $M$ $=100$ dan $N=256$. 


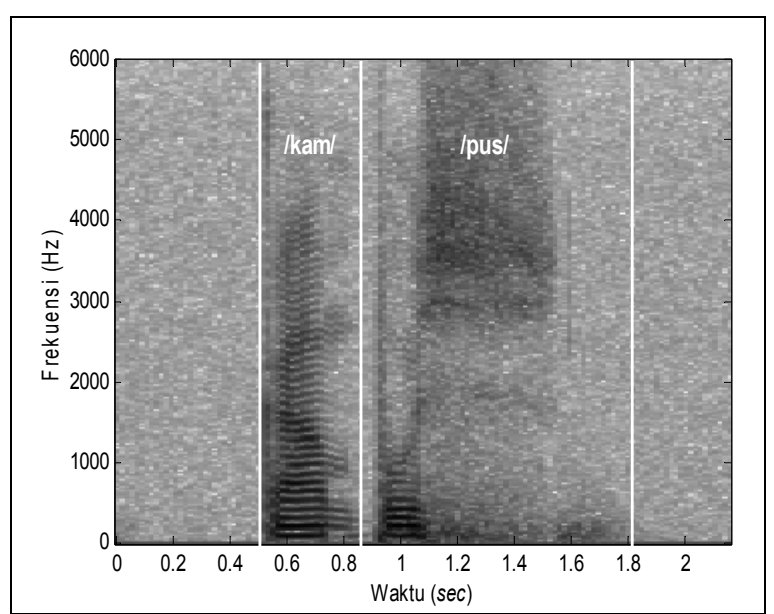

Gambar 14. Spektogram sinyal wicara/kampus/, $M$ $=200$ dan $N=512$.

Untuk $N=128$ mempunyai resolusi tinggi terhadap waktu. Frame mempunyai periode waktu sangat singkat. Hasil ini menunjukkan bahwa sinyal untuk sebuah frame tidak mengubah alamiahnya (untuk vokal atau konsonan yang sama). Untuk $N=256$ mempunyai kompromi antara resolusi waktu dan resolusi frekuensi.Untuk $N=512$ mempunyai resolusi frekuensi yang bagus tetapi ada frame-frame yang kurang, artinya bahwa resolusi dalam waktu direduksi dengan kuat. Nilai $N=256$ adalah kompromi yang dapat diterima. Lebih jauh jumlah frame adalah relatif lebih kecil, sehingga mengurangi waktu komputasi.

Selanjutnya filter bank yang digunakan untuk proses mel frekuensi ada 20 dan frekuensi sampling-nya $12000 \mathrm{~Hz}$ hasilnya seperti dalam Gambar 16.

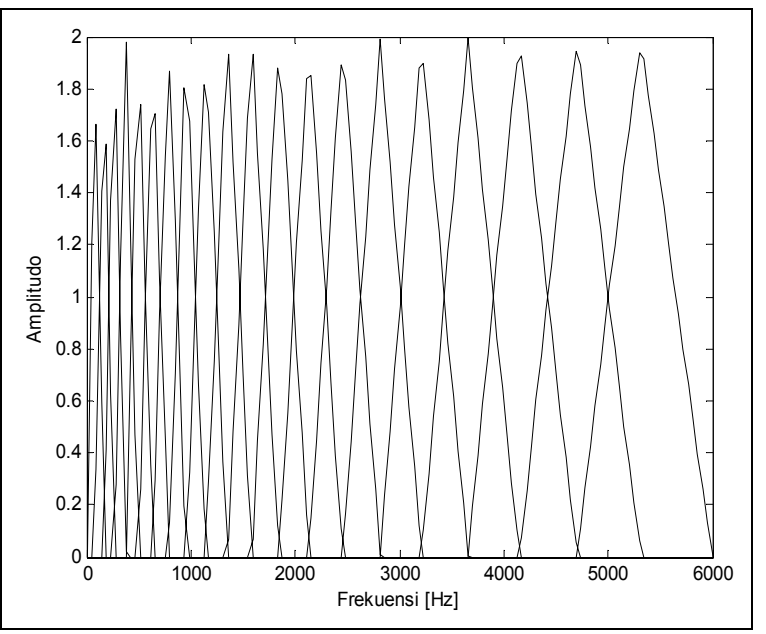

Gambar 15. Hasil filter bank dalam proses mel frekuensi.

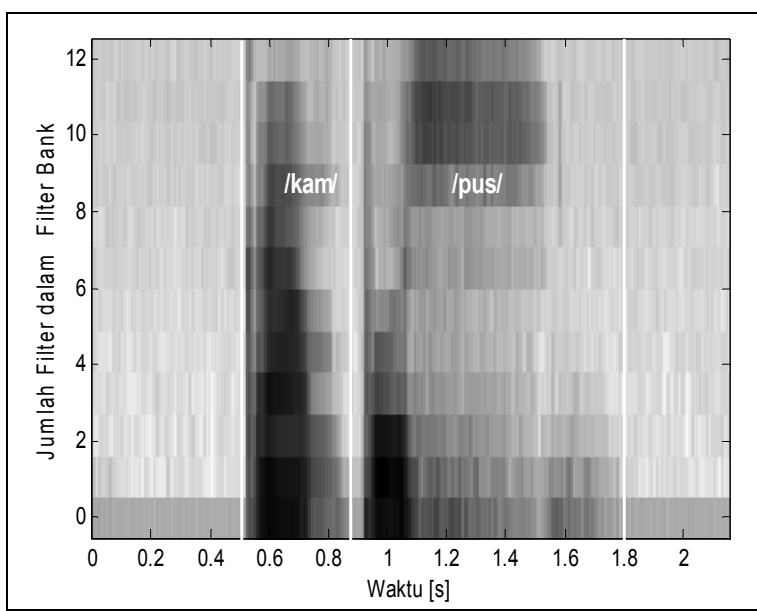

Gambar 16. Spektrum daya dimodifikasi dengan mel cepstrum filter $(M=100, N=256)$.

\section{ANALISA MFCC DAN VQ}

Kinerja sistem pengenalan penutur tergantung pada besarnya data test dan data train. dalam rekaman, peralatan yang digunakan dalam proses rekaman suara dan jumlah penutur yang sedikit dalam kelompok pelatihan dan pengetesan. Laju kebenaran untuk seluruh sistem identifikasi sistem adalah 100\% dengan proses rekaman yang sangat cermat dan pengaturan parameter-parameter yang relevan, seperti ukuran codebook, jumlah iterasi dan lain-lain. Uji vektor kuantisasi menggunakan koefisien mel frekuensi 12, filter bank 20 dan 16 centroid.

Pelatihan dilakukan dengan 10 penutur dengan mengucapkan kata /kampus/, masing-masing penutur berbeda, dengan proses mel frequency wrapping dan vektor kuantisasi. Gambar 17 dan Gambar 18 menunjukkan plot dua dimensi yang dilatih dengan vektor-vektor MFCC untuk dua penutur dengan dimensi ke-9 dan ke-10 dengan 12 koefisien mel frequency dan perbandingan dua dimensi untuk plot codebook yang dibangkitkan oleh dua penutur menggunakan dua dimensi yang sama dengan ukuran codebook 16. Masing-masing codeword merepresentasikan hubungan kluster dengan titik-titik data MFCC dan secara akurat merepresentasikan karakteristik suara masing-masing penutur.

Dalam vektor kuantisasi, jarak ecluidean dihitung antara kata dan codebook yang tak dikenal, kemudian nilai terendah dari jarak tersebut diidentifikasi sebagai suara penutur yang benar. Hasil untuk ukuran codebook 16 untuk 10 penutur adalah $32.889,38.263$, 41.579, 41.004, 50.192, 35.520, 47.696, 47.403, 56.719, dan 29.044 . 


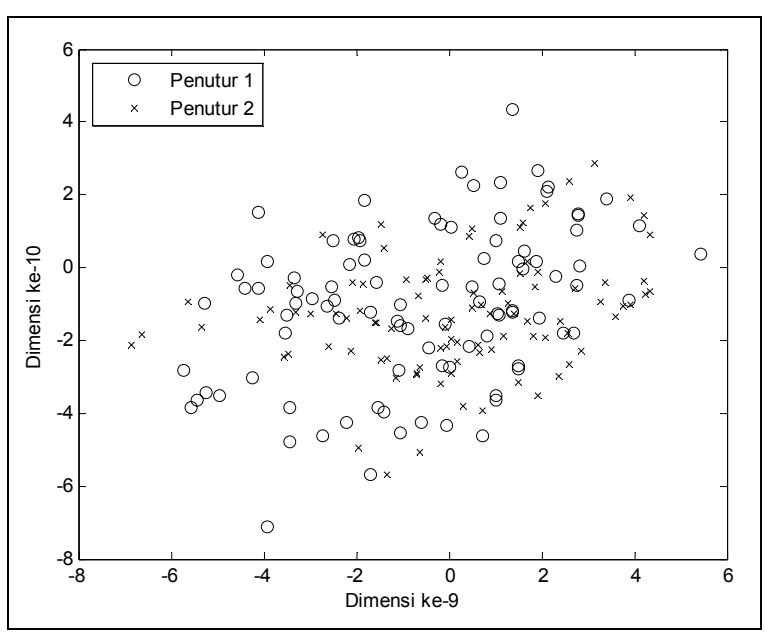

Gambar 17. Sebaran vektor-vektor akustik dari dua penutur dalam proses mfcc 12 dan filter bank 20, dan 16 centroid $(N=256, M=100)$.

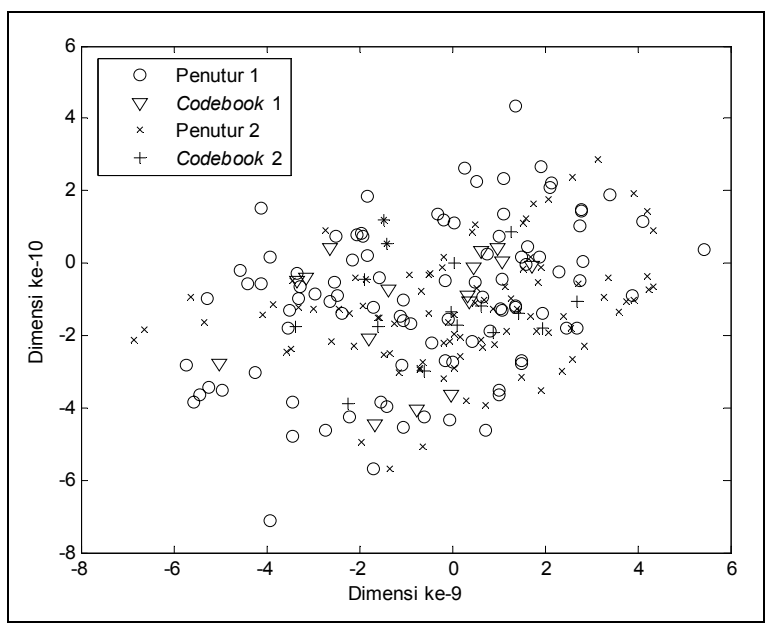

Gambar 18. Sebaran vektor-vektor akustik dari dua penutur dan codebook-nya, mfcc 12, filter bank 20 , dan 16 centroid $(N=256, M=100)$.

Tabel 1. Hubungan Jarak Euclidean antar Penutur untuk Empat Penutur

\begin{tabular}{lrrrr}
\hline & Penutur & Penutur & Penutur & Penutur \\
& \multicolumn{1}{c}{$\mathbf{1}$} & $\mathbf{2}$ & $\mathbf{3}$ & $\mathbf{4}$ \\
\hline Penutur 1 & 5.0609 & 14.8146 & 15.0358 & 13.0911 \\
Penutur 2 & 17.4570 & 5.7034 & 12.8706 & 13.5058 \\
Penutur 3 & 16.6471 & 13.2394 & 5.9544 & 12.5522 \\
Penutur 4 & 14.4681 & 13.2555 & 11.7277 & 5.7707 \\
\hline
\end{tabular}

Akan tetapi, hal ini sukar untuk memberikan nilai ambang untuk jarak pada penutur lain yang mencoba mengakses database dan penutur yang ada dalam database pelatihan berdasarkan urutan pengetesan, sebagai ilustrasi dalam Tabel 1. menunjukkan nilainilai test vektor kuantisasi artinya bahwa penutur 1 mempunyai jarak yang kecil dengan penutur 1 dibandingkan dengan penutur-penutur lainnya, maka penutur 1 cocok dengan penutur 1. Sedangkan dalam Tabel 2. menunjukkan jarak Euclidean terkecil untuk sepuluh penutur. Karena nilai ambang bervariasi untuk masing-masing kata, sehingga jika nilai ambang ditentukan, maka banyak nilai-nilai lain menjadi terlalu tinggi atau terlalu rendah. Sehingga keterbatasan sistem ini adalah orang-orang yang belum dilatih dalam sistem ini masih dapat lolos dengan melalui algoritma vektor kuantisasi. Keterbatasan ini tidak diharapkan. Untuk penutur yang dilatih dalam database untuk mengakses sistem ini, vektor kuantisasi membantu untuk mengolah password penutur dalam database dan memperbaiki keamanan dari keseluruhan sistem dan melayani keseluruhan sistem keamanan.

Tabel 2. Jarak Euclidean Terkecil untuk MasingMasing Penutur

\begin{tabular}{lc}
\hline & Jarak euclidean \\
\hline Penutur 1 & 5.0609 \\
Penutur 2 & 5.7034 \\
Penutur 3 & 5.9544 \\
Penutur 4 & 5.7707 \\
Penutur 5 & 6.5507 \\
Penutur 6 & 5.4490 \\
Penutur 7 & 6.4143 \\
Penutur 8 & 6.2931 \\
Penutur 9 & 6.7853 \\
Penutur 10 & 5.0141 \\
\hline
\end{tabular}

\section{KESIMPULAN}

Penelitian ini untuk membuat sistem pengenalan penutur. Ekstraksi ciri wicara dari penutur tak dikenal dan dibandingkan dengan ekstraksi ciri dari penutur yang ada dalam database. Ekstraksi ciri menggunakan mel frequency wraping yaitu dengan MFCC. Fungsi mel cepstrum digunakan untuk menghitung sinyal mel. Penutur dimodelkan dengan menggunakan VQ. Codebook VQ dibangkitkan uleh kluster dari pelatihan vektor-vektor ciri dari masingmasing penutur dan disimpan dalam database. Dalam metode ini, algoritma $K$-mean digunakan untuk kluster. Dalam tahap pengenalan penutur, distorsi diukur berdasarkan minimisasi jarak Euclidean yang digunakan saat mencocokkan (matching) penutur tak dikenal dengan database penutur. Dengan MFCC dan VQ pengenalan penutur dapat digunakan untuk identifikasi penutur.

\section{UCAPAN TERIMAKASIH}

Terima kasih ditujukan pada Fakultas Teknik Universitas Brawijaya yang telah membiayai penelitian ini melalui anggaran DPP tahun 2007. 


\section{DAFTAR PUSTAKA}

[1] Sigurdsson S, Petersen K.B dan Schiøler TL, "Mel Frequency Cepstral Coefficients: An Evaluation of Robustness of MP3 Encoded Music", University of Victoria, 2006.

[2] Kuldip K.P dan Bishnu S.A, "Frequency-Related Representation of Speech", EUROSPEECH Seminar 2003 - Geneva

[3] Irino T, Minami $Y$, Nakatani T, Tsuzaki $M$, dan Tagawa H, "Evaluation of a Speech Recognition/ Generation Method Based on HMM and Straight', Presented at ICSLP2002 Denver, Colorado

[4] Rabiner L.R dan Juang B. H, "Fundamentals of Speech Recognition", Prentice-Hall, Englewood Cliffs, N.J., 1993.
[5] Furui S, "An overview of speaker recognition technology", ESCA Workshop on Automatic Speaker Recognition, Identification and Verification, pp. 1-9, 1994.

[6] Xu, Tan, Dalsgaard dan Lindberg "Exploitation of spectral variance to improve robustness in speech recognition", Electronic Letters, 2nd March 2006 Vol. 42 No. 5

[7] Ludeman, L.C, "Fundamentals of Digital Signal Processing", Happer \& Row Publishers, New york, 1986

[8] Song F.K, Rosenberg dan Juang B.H , "A vector quantisation approach to speaker recognition", AT\&T Technical Journal, Vol. 66-2, pp. 14-26, March 1987.

[9] Furui, S, "Digital Speech Processing, Synthesis, and Recognition", Marcel Dekker Inc.New York, 1989 